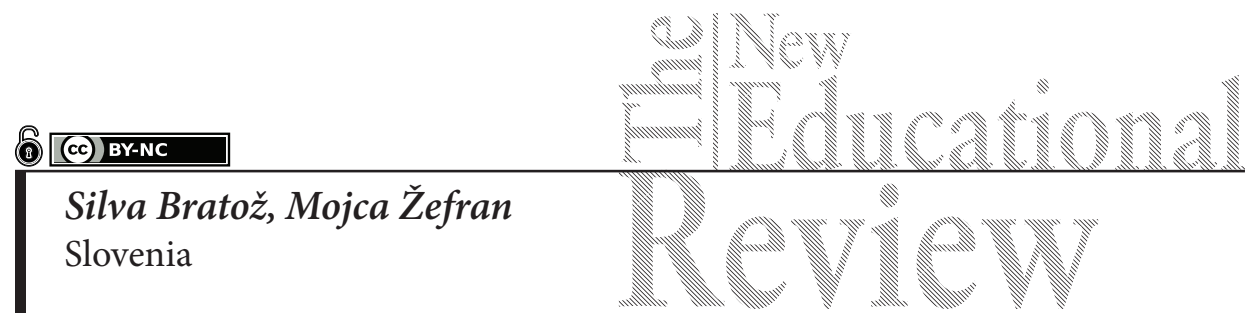

\title{
Systematicity in Foreign Language Classroom Communication
}

DOI: $10.15804 /$ tner.2018.53.3.06

\begin{abstract}
The paper discusses the intrinsic potential offered by classroom interaction for language development. The first part examines several theoretical aspects and characteristics of classroom communication. The second part presents the results of a study which investigates different aspects of classroom interaction in foreign language teaching and the strategies used to encourage classroom communication in the target language. The study, which combines quantitative and qualitative research methods, is based on a survey of Slovene teachers teaching English in primary school. Results suggest that while the respondents are well aware of the benefits of using English in classroom communication, they generally use it in an arbitrary and unsystematic fashion. We would like to argue that we can contribute to the effectiveness of the teaching process by approaching classroom communication with a systematic and consistent format.
\end{abstract}

Keywords: classroom interaction, English as a foreign language, primary education, routine classroom communication

\section{Introduction}

Classroom discourse has often been associated with replicating genuine or natural communication in class, a line of reasoning which is in keeping with the principles of the communicative approach, which takes a pragmatic or perfor- 
mance-based perspective to learning. It is aimed at developing communicative competence through the use of real-life situations in which learners are perceived as active conversational participants, who interact and negotiate the type of input they receive. In the process of exchanging turns and roles with their teacher and their peers, learners are exposed to a number of characteristic communication patterns which can effectively be exploited for foreign language (FL) teaching purposes. Furthermore, classroom interaction (as opposed to some other types of interaction) is characterised by a high frequency of activities, such as turn-taking, giving instructions, maintaining discipline, as well as a wide range of other routine practices and characteristic communication patterns, allowing for an almost unlimited repertoire of repetitions. While this constant and natural exposure offers a vast intrinsic potential in FL instruction, teachers often lack efficient strategies to encourage learners to switch to their FL classroom interaction mode and make the most of their FL classes. This proves to be especially hard to achieve in peer-peer interaction.

In the literature review, we find that there are several ways of referring to the language used between teachers and students in an FL classroom which does not have a specific pedagogical objective reflected in the teaching content, from 'classroom interaction' (Seedhouse, 1996; Gil, 2002) and 'classroom discourse' (Christie, 2005; Walsh, 2006b), 'teacher talk' (Cullen, 2002; Ellis, 1994) and 'teacher-fronted interaction' (Garton, 2012; Walsh, 2006a), to more generally used expressions, such as 'classroom language', 'classroom communication' and 'classroom English'. While several of these terms are often used interchangeably, some are clearly related to the analysis of specific aspects of this type of communication. Ellis (1994, p. 726), e.g., foregrounds the functional aspect of language by defining 'teacher talk' as the process through which "teachers address classroom language learners differently from the way they address other kinds of classroom learners. They make adjustments to both language form and language function in order to facilitate communication". On the other hand, Walsh (2006b, p. 3) focuses on special communication patterns found in language classrooms and features of classroom discourse, such as elicitation techniques or repair strategies. As discussed by Mahasneh, Musslim and Shammout (2016), learner-teacher interactions can also be viewed from the broader perspective of classroom learning environments and systems theory, according to which the behaviours of different participants in a social situation both determine and are determined by each other. For the purposes of this paper, we understand classroom communication broadly as 'a form of institutional communication' which has its special characteristics and involves both teacher-learner and learner-learner interaction. 
The importance of interactional competence in the classroom has been discussed by several authors (Walsh, 2006b; Christie, 2002; Seedhouse, 1996), revealing different approaches and methodologies. On the one hand, the complex and dynamic nature of FL classroom interaction has been explored from the discourse analytic perspective, with a clear objective of understanding the nature of this type of discourse (Christie, 2002; Seedhouse, 1996). On the other hand, classroom communication has been explored from a pedagogical perspective with the ultimate goal of enhancing teaching practice. Several attempts have been made to bridge the gap between the two approaches by combining recent studies from the field of discourse analysis with reflective practices for teacher development (Walsh, 2006b; 2002; Garton, 2012). For example, arguing in favour of an increased interactional awareness, Walsh (2006a) presents a model of the self-evaluation of teacher talk (SETT), a tool intended for FL teachers to assess their own classroom interaction. The SETT instrument consists of several stages of the teacher's self-evaluation based on audio-recordings of their own lessons and a reflective feedback interview with the author. It is used to identify different modes of discourse with a view to raising the awareness of the importance of interaction in the classroom.

\section{Research Problem}

Back in 1981, Hughes (1981, p. 5) maintained that teachers should be trained in specialised classroom competence, using English "both as the goal of their teaching and as the primer medium of instruction and classroom management". In this context, classroom discourse is perceived as an end rather than solely a means of achieving a particular language competence, enhancing the effectiveness and relevance of the teaching process. In addition, several authors have pointed out that classroom communication can be seen as a useful source of language input at all levels of foreign language teaching, including young learners (Cameron, 2001; Scott \& Ytreberg, 1994). Scott \& Ytreberg (1994, p. 22) explicitly maintain that we should start with giving genuine instructions in English the moment the pupils start learning English, while the practice of using the foreign language in classroom communication is also supported by parents (Pižorn and Fojkar, 2016). However, while most teachers are well aware of the many benefits of using English in FL classroom communication, they often lack systematic strategies to establish an efficient interaction in the foreign language. This may be further enhanced in the context of teaching young language learners, in which teachers often have inadequate foreign language competences (Brumen and Fojkar, 2012). 


\section{Research Focus}

The overall aim of the research was to identify the extent to which English is used in both teacher-learner and learner-learner interaction in FL classes. In addition, the purpose of the study was to investigate different strategies and approaches employed by teachers in order to encourage classroom communication in English. The paper, therefore, addresses three main questions: 1. To what extent do learners participate in classroom interaction in English?, 2. What is teachers' attitude towards the role and significance of classroom interaction in the foreign language? and 3 . What strategies do teachers use to encourage classroom interaction in English?

\section{Research Methodology}

\section{General background}

The study investigates different aspects of classroom interaction in foreign language teaching as well as strategies used to encourage classroom communication in the target language. It combines qualitative and quantitative research methods and is based on a survey carried out among Slovene teachers teaching English in primary school. The respondents were asked to give feedback on the following points:

a. the extent to which English is used in classroom communication during English lessons,

b. the extent to which English is used in carrying out various classroom activities,

c. whether the participants encourage learners to communicate in English in classroom communication,

d. whether the teachers plan the use of English in classroom communication,

e. different strategies used to encourage learner-learner classroom communication in English,

f. possible obstacles to using English for classroom communication.

\section{Sample}

The participants were all teachers of English in primary school. The sample comprises 114 returned questionnaires. Figure 1 and Figure 2 show the respondents' age and teaching experience. 


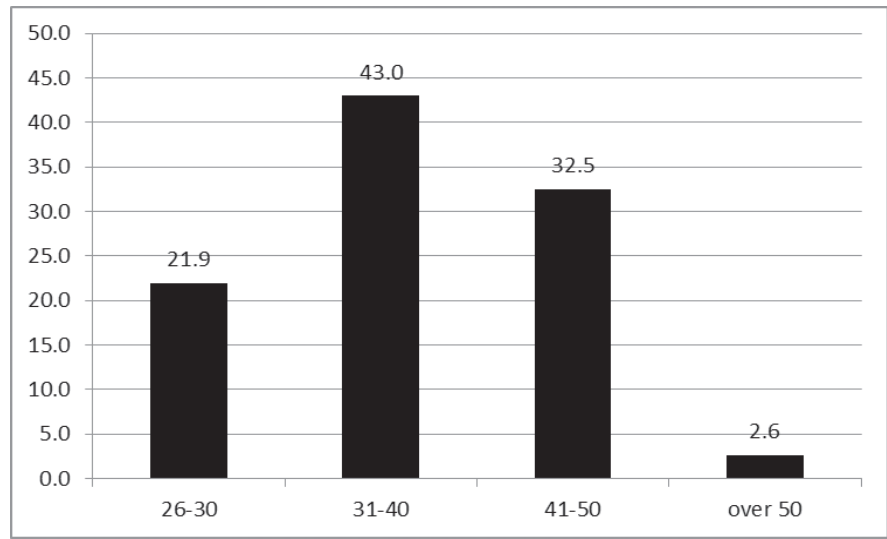

Figure 1. Respondents' age

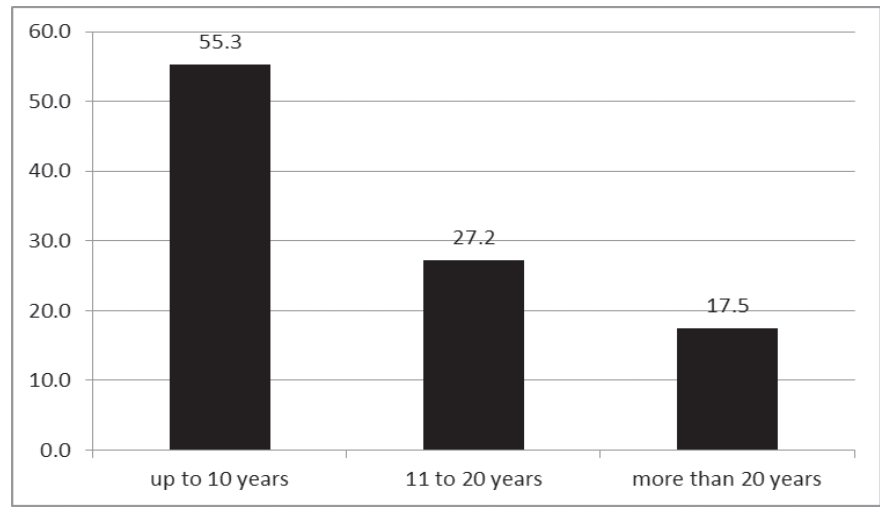

Figure 2. Respondents' teaching experience

\section{Instrument and procedures}

An online questionnaire was drawn up, consisting of 12 questions including follow-up questions. The first two questions referred to the respondents' age and teaching experience. The next four questions were aimed at identifying the extent to which English is used as a language of communication in the respondents' classrooms, then four questions referred to the respondents' attitudes towards the importance of using English in classroom communication. Finally, the participants were asked to report on the strategies used to encourage classroom communication in English and any obstacles perceived in doing so. The link to the 
questionnaire was sent to two sources: the mailing list of all the primary schools in Slovenia and the IATEFL Slovenia mailing list.

\section{Data Analysis}

The quantitative data were analysed using the SPSS statistical software package. The results are presented as frequency and percentage distributions. The reliability of the instrument was tested with Cronbach's alpha, which showed that the questionnaire had good internal consistency: $\alpha=.77$. The qualitative data were analysed with qualitative content anaysis.

\section{Results}

The first four questions were aimed at identifying the extent to which English is used as a language of communication in the respondents' classrooms. The teachers were first asked to give an estimate of the extent to which English is used for classroom communication in their English classes.

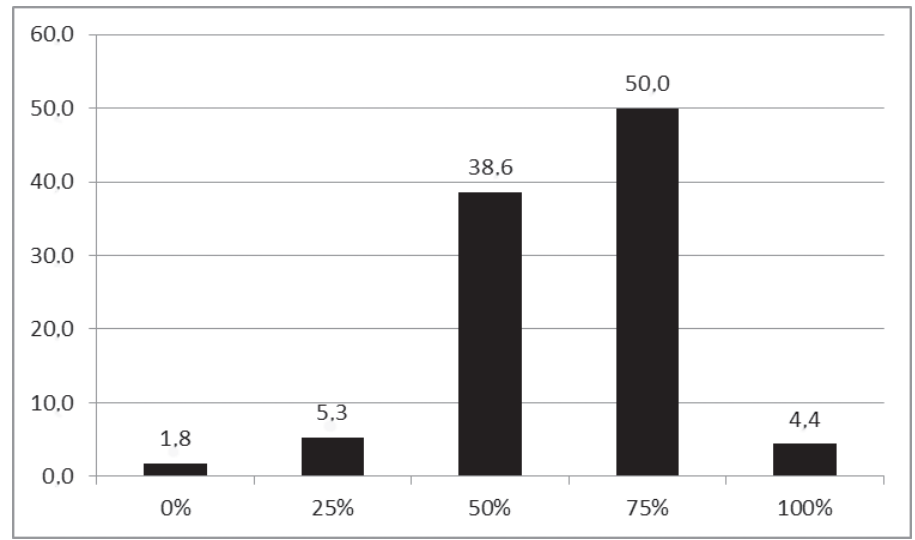

Figure 3. Use of English for classroom interaction

As can be seen in Figure 3, 50\% of the respondents use English 75\% of the time and more than $38 \%$ use English half of the time. We were also interested in the correlation between the respondents' age and work experience on the one hand and the extent of English use in classroom communication on the other but the correlation turned out to be statistically insignificant (age: $\chi 2=18.376, g=12$, $\mathrm{P}=.105$, teaching experience: $\chi 2=8.190, \mathrm{~g}=8, \mathrm{P}=.415)$.

The next question concerned the extent to which English is used in carrying out the following classroom activities during English lessons: greeting, presenting new 
teaching content, instructions, explaining grammar, presenting new vocabulary, checking comprehension, positive feedback, negative feedback, disciplining, set phrases, such as be quiet, excuse me, and classroom management.

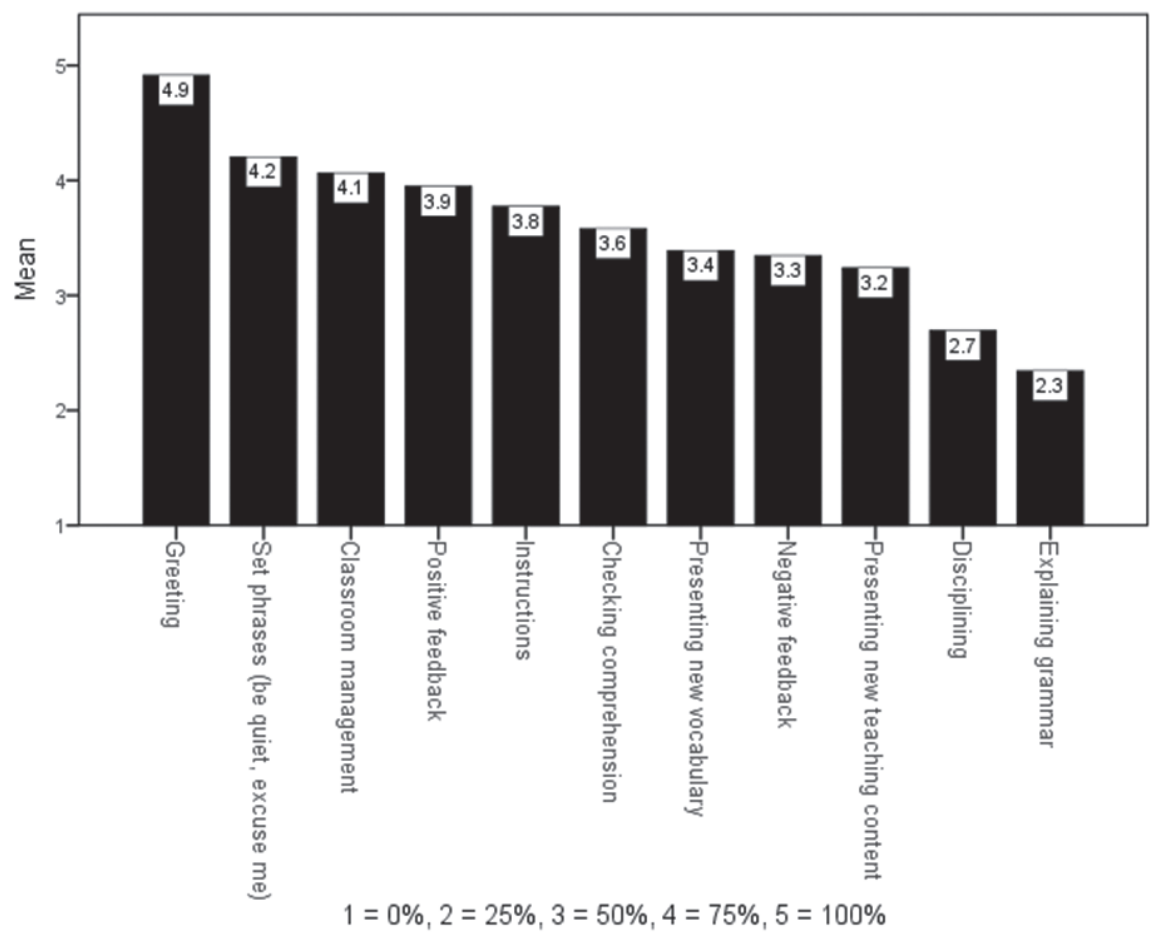

Figure 4. Use of English in different classroom activities

As can be seen in Figure 4, with the majority of activities, English is used on average more than $50 \%$, and with some activities, such as greetings, almost $100 \%$. On the other hand, activities more directly aimed at attaining specific pedagogical goals, such as presenting new teaching content and explaining grammar, were reported to be less frequently (less than 50\%) conducted in English. Of the activities which are not directly related to particular teaching objectives, disciplining stands out as the one in which L1 is used more than L2. In addition, the standard deviation for this activity was higher than for other activities $(\mathrm{SD}=1.08)$, suggesting a larger variation in the responses. A possible interpretation of this would be that the teachers employ a number of different strategies for dealing with this aspect of classroom interaction. 
The third and fourth questions were aimed at identifying the extent to which pupils use English in communication with their teachers and their peers.

As expected, pupils use English more frequently when they interact with their teachers than when they interact with each other. Figure 5 shows an interesting mirror image in which learner-teacher interaction in English is in an almost exact inverse order to the learner-learner interaction.

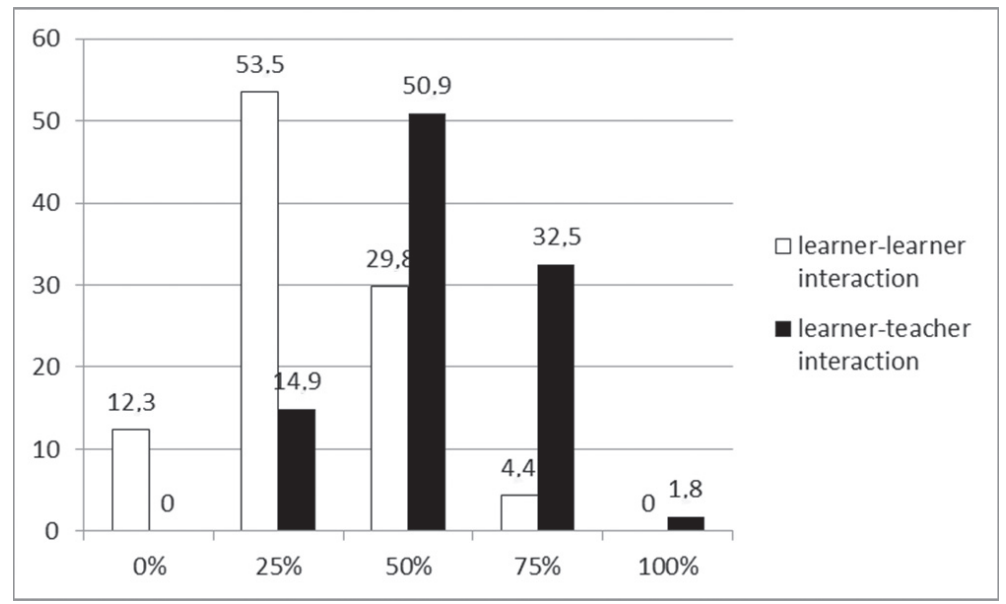

Figure 5. Learner-teacher and learner-learner interaction in English

The next four questions were aimed at identifying the teachers' attitude towards the role and significance of classroom communication in foreign language instruction.

When asked whether they plan the use of English in classroom communication (Figure 6), the majority of the respondents (80.7\%) chose 'no' and only $15.8 \%$ said 'yes.' On the other hand, more than half of the respondents (51.8\%) agreed that it would be a good idea if classroom communication in English was taught as part of course content (Figure 7).

As can be seen in the pie-chart above (Figure 8), when asked about encouraging learners to use English in classroom communication, the vast majority of the respondents $(87.7 \%)$ reported that they encourage the use of English. In the follow-up question, they were asked to comment on the strategies used to encourage English in classroom interaction. Table 1 shows the strategies most frequently listed by the respondents and a selection of the teachers' comments reflecting a particular strategy. Four main strategies have been identified. The majority of the respondents (52\%) encourage the use of English in their classes 


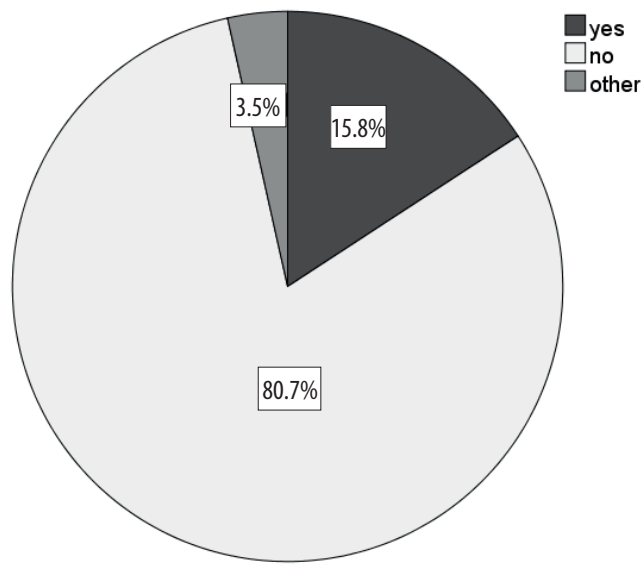

Figure 6. Planning the use

of English in classroom interaction
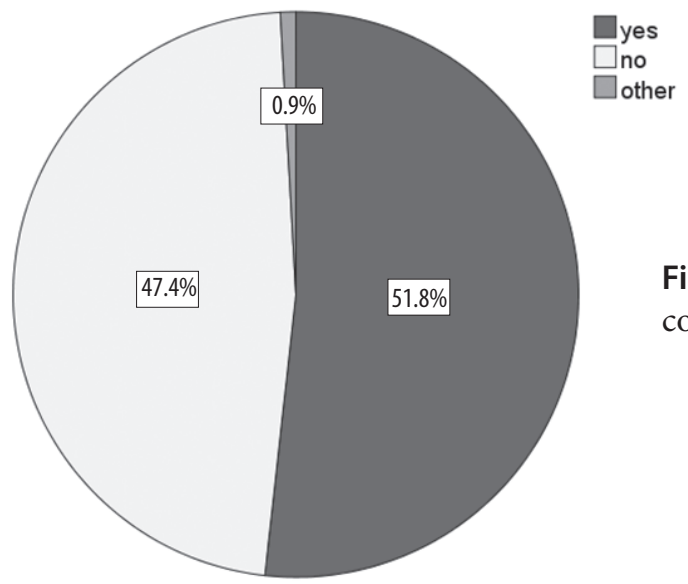

Figure 7. Teaching classroom communication as part of course content

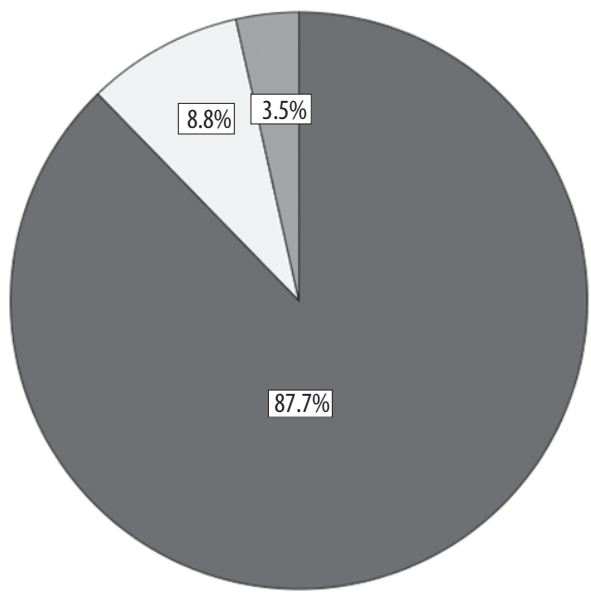

Figure 8. Encouraging the use English in classroom communication 
by insisting on it or demanding it, $7 \%$ of the respondents commented that they focus on pre-teaching classroom language, 4 respondents said that they set an example by using English consistently themselves and 2 use focused activities, such as dialogues or team work.

Table 1. Strategies for encouraging classroom interaction in English

\begin{tabular}{lcl}
\hline \multicolumn{1}{c}{ STRATEGY } & NO. & \multicolumn{1}{c}{ EXAMPLES OF COMMENTS } \\
\hline $\begin{array}{l}\text { insisting, pretending } \\
\text { not to hear }\end{array}$ & 59 & $\begin{array}{l}\text { I pretend not to hear something if it is not said in English. } \\
\text { I say “Can you say that again in English, please? Speak Eng- } \\
\text { lish, please." } \\
\text { I don't understand their questions unless they ask them in } \\
\text { English. } \\
\text { I ignore their answers if they are not in English. } \\
\text { I simply demand it. }\end{array}$ \\
\hline $\begin{array}{l}\text { by setting an example } \\
\text { pre-teching } \\
\text { classroom language }\end{array}$ & 4 & $\begin{array}{l}\text { I serve as an example. I use English all the time, it's part of our } \\
\text { routine, it's our 'game'. }\end{array}$ \\
\hline using focused activities & 2 & They have the main expressions on posters. \\
\hline
\end{tabular}

Aside from the strategies above, some teachers mentioned other resourceful ways of getting learners to use English. For example, one of the teachers said that they have separate 'English only' classes, yet another suggested making learners play the role of the teacher. In addition, one of the respondents said that in her classes classroom interaction is formally assessed.

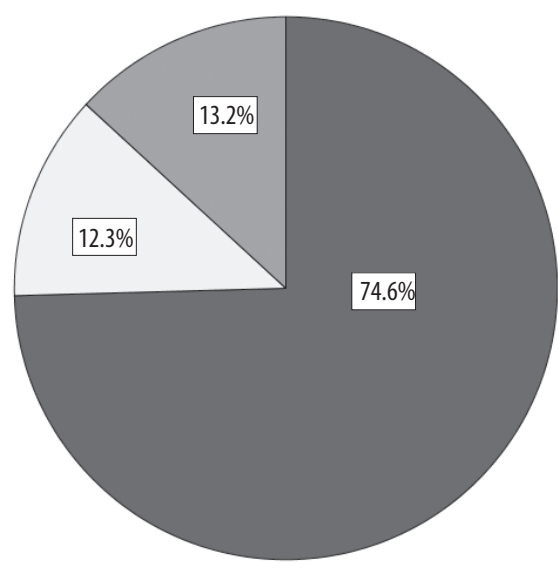

Figure 9. Encouraging the use of in English in learner-learner interaction 
We were also interested in learning if the teachers who participated in the survey encourage learner-learner interaction in English. The pie chart above (Figure 9) shows that the majority of the respondents $(74.6 \%)$ do.

Finally, the teachers were asked whether they perceive any obstacles to the use of English in classroom communication.

Table 2. Obstacles to the use of English in classroom communication

\begin{tabular}{|c|c|c|}
\hline OBSTACLES & NO. & EXAMPLES OF COMMENTS \\
\hline $\begin{array}{l}\text { mixed levels, } \\
\text { learners with } \\
\text { lower levels of } \\
\text { English compe- } \\
\text { tence }\end{array}$ & 22 & $\begin{array}{l}\text { It is difficult to use English in classroom communication in larger } \\
\text { mixed-level classes, where there's a huge gap between the strongest and } \\
\text { the weakest pupils. } \\
\text { Weak pupils feel even weaker when they don't understand instructions } \\
\text { in English. } \\
\text { The problem are also students whose English is very good, who always } \\
\text { want to speak and we often have to hold them back. }\end{array}$ \\
\hline consistency & 11 & $\begin{array}{l}\text { Not all teachers do this and this is really a problem when one takes over } \\
\text { a class from another teacher. } \\
\text { If you don't do this from the beginning, learners find it strange and } \\
\text { unnatural. } \\
\text { One just has to be persistent and consistent, which is not always easy. } \\
\text { The problem is I'm personally not consistent enough. } \\
\text { If we start from the beginning and build it gradually, there shouldn't } \\
\text { be any problems. However, when I started teaching like that in the 5th } \\
\text { grade, the pupils were 'outraged' because I used so much English. Even } \\
\text { their parents took it badly. }\end{array}$ \\
\hline $\begin{array}{l}\text { mother tongue } \\
\text { preference }\end{array}$ & 10 & $\begin{array}{l}\text { Some learners resort to Slovene too quickly. } \\
\text { English is not a natural communication channel for them so a lot of } \\
\text { motivation is necessary. } \\
\text { When the children are not monitored and work on their own (in } \\
\text { groups), they use Slovene even if instructed to use English. } \\
\text { Although the children understand English, they prefer using Slovene. }\end{array}$ \\
\hline $\begin{array}{l}\text { young learners' } \\
\text { low language } \\
\text { level }\end{array}$ & 7 & $\begin{array}{l}\text { Young learners just don't understand enough English. } \\
\text { A lot of patience and repetition is necessary, especially with young } \\
\text { learners. }\end{array}$ \\
\hline $\begin{array}{l}\text { anxiety, lack of } \\
\text { willingness to } \\
\text { communicate } \\
\text { in English }\end{array}$ & 10 & $\begin{array}{l}\text { Some learners prefer not to expose themselves with speaking in Eng- } \\
\text { lish. } \\
\text { Some pupils are reluctant to use English because they feel they won't be } \\
\text { able to express themselves. } \\
\text { Children with poor knowledge are reluctant to cooperate because they } \\
\text { feel they are being assessed all the time and they're afraid they will say } \\
\text { something wrong. }\end{array}$ \\
\hline time & 4 & $\begin{array}{l}\text { It's too time-consuming. } \\
\text { I sometimes resort to Slovene when I'm pressed for time. }\end{array}$ \\
\hline
\end{tabular}


The most frequently mentioned obstacle, reported by 22 respondents, was the problem of mixed levels within one single classroom, while the next (reported by 11 respondents) referred to difficulties with establishing consistency. Several respondents (10) reported that pupils often automatically resort to their mother tongue. Another obstacle, mentioned by 10 teachers, refers to the perceived anxiety and reluctance to communicate in English. As can be seen in Table 2, 7 teachers believe that it is more difficult to use classroom communication with young learners, while 4 respondents expressed their opinion that working on establishing classroom communication would be too time-consuming.

\section{Discussion}

The results of the study reveal two significant aspects of the way classroom communication in English is implemented in practice. First, the fact that half of the teachers surveyed use English 75\% of the classroom time suggests that classroom interaction is widely perceived as a tool for enhancing FL teaching and learning. However, this is mostly the case in teacher-learner interaction, while the estimates for English used in learner-learner interaction are still relatively low. As we saw above, the frequency of learner-teacher interaction in English is in an almost exact inverse order to the learner-learner interaction. This outcome suggests that there might be clear advantages in developing strategies for improving learner-learner interaction in English. It is also clear that the majority of the respondents do not plan their use of language in advance. They often switch to the learners' mother tongue when it comes to disciplining, presenting new content or explaining grammar. This leads to the conclusion that the teachers do not have clearly defined strategies of language use in the FL classroom and that their language choices are largely made on impulse.

Four questions were aimed at identifying the teachers' attitude towards the role and significance of classroom communication in foreign language instruction. When asked whether they plan when they use English in classroom communication, four-fifths of the respondents said they do not. However, the vast majority of the teachers surveyed indicated that they encourage the use of English, both as part of classroom communication and in learner-learner interaction. In addition, a little more than half are in favour of teaching classroom communication in English as part of course content. From this we may conclude that while the respondents are undoubtedly aware of the benefits of using classroom communication for language development, they are unsure as to whether this aspect should 
be exploited systematically. This is also reflected in the responses to the follow-up question, in which they were asked to comment on the strategies used for encouraging English in classroom interaction. The most common approaches used, i.e., 'insisting', 'pretending not to hear' are more or less effective persuasion attempts rather than fully elaborated strategies. This is eloquently illustrated by one of the teachers, who remarked that she simply demands learners to speak English.

While the respondents do encourage learners to use L2 as much as possible in the FL classroom, they themselves often turn to Slovene when presenting new content, explaining grammar and disciplining. In addition, they perceive several obstacles to using English for classroom communication. The most frequently mentioned obstacle refers to the problem of mixed levels within one single classroom, a problem which involves both pupils with high levels of English because as one teacher commented "they always want to speak and we often have to hold them back" as well as weaker pupils, who might find it difficult to follow instructions in English let alone be able to express themselves efficiently. Another difficulty mentioned by the participants in the survey is the preference of using L1, which is a more 'natural channel' for the learners when they communicate freely among each other. What is more, this preference is often related to unwillingness to communicate in L2 and FL anxiety, which is a considerable problem as shown by Žefran (2015) in her retrospective study of learners' attitudes towards learning English, which showed that learners exhibit relatively high levels of FL anxiety. We would like to argue that such obstacles could be efficiently tackled by approaching classroom communication in ELT with a methodical and consistent format. Finally, the very fact that the teachers see lack of consistency as a major obstacle to establishing effective classroom communication in L2 suggests that classroom comunication should indeed be dealt with consistently and systematically.

\section{Conclusion}

It has become widely accepted that the classroom setting offers abundant opportunities for developing genuine use of language aimed at enhancing foreign language learning and acquisition. We have argued that there is a vast intrinsic potential in it for meaningful language development. Several issues discussed in the article are worth investigating further, from looking more closely into the nature of classroom discourse to examining ways of developing classroom interaction in L2 systematically and consistently. The case study presented in this paper showed that although teachers are cognisant of the potential offered by 
classroom discourse in increasing the effectiveness of foreign language teaching, they often lack efficient strategies to encourage learners to use English in their communication with the teachers and their peers. The results of the survey also suggest that there is clear potential in learner-learner classroom communication, which is particularly unexploited compared to teacher-learner interaction. Finally, we would like to stress that while we agree with the commonly held view that the most efficient way of teaching English is by using it as much as possible, we also believe that we can make the most of it only by applying a systematic approach.

\section{References}

Behnam, B. \& Pouriran Y. (2009). Classroom discourse: Analyzing teacher/learner interactions in Iranian EFL task-based classrooms. Porta Linguarum, 2: 117-132.

Brumen, M., \& Fojkar, M.D. (2012). Teacher development in Slovenia for teaching foreign languages at the primary level. CEPS Journal: Center for Educational Policy Studies Journal, 2(3), 27.

Cameron, L. (2001). Teaching Languages to Young Learners. Cambridge: Cambridge University Press.

Christie, F. (2005). Classroom Discourse Analysis: A Functional Perspective. London: Continuum International Publishing Group Ltd.

Cullen, R. (2002). Supportive teacher talk: the importance of the F-move. ELT Journal, 56(2), $117-127$.

Ellis, R. (1994). The study of second language acquisition. Oxford, MA: Oxford University Press.

Garton, S. (2012). Speaking out of turn? Taking the initiative in teacher-fronted classroom interaction. Classroom Discourse, 3(1), 29-45.

Gil, G. (2002). Two complementary modes of foreign language classroom interaction. ELT Journal, 56(3), 273-279.

Hughes, G.S. (1981). A Handbook of Classroom English. Oxford: Oxford University Press.

Lightbown, P. and Spada N. (2006). How languages are learned. Oxford: Oxford University Press.

Mahasneh, A.M. and Musslim, F.Y. \& Shammout, N.A. (2016). Student Perceptions of Science Teacher Communication Behavior in Jordan. The New Education Review, 45(3), 210-222.

Pižorn, K., \& Fojkar, M.D. (2013). Parents and Educational Change - the Need for Reculturing Parents in Lowering the Starting Age of Foreign Language Learning. The New Education Review, 34(4), 63-73.

Scott, W. A. and Ytreberg, L.H. (1994). Teaching English to Children. New York: Longman Inc.

Seedhouse, P. (1996). Classroom interaction: possibilities and impossibilities. ELT Journal, $50(1), 16-24$.

Walsh, S. (2006a). Talking the talk of the TESOL classroom. ELT Journal, 60(2), 133-141.

Walsh, S. (2006b). Investigating Classroom Discourse. London and New York: Routledge. 